\title{
Effect of Voice Therapy for Persistent Dysphonia Following Laryngeal Microsurgery
}

\author{
Ji-Sung Kim ${ }^{\mathrm{a}, \mathrm{b}}$, Seong Hee Choi ${ }^{\mathrm{c}}$, Chul-Hee Choi ${ }^{\mathrm{c}}$, Dong-Wook Lee ${ }^{\mathrm{d}}$ \\ ${ }^{a}$ Graduate School of Daegu Catholic University, Gyeongsan, Korea \\ ${ }^{b}$ Department of Otorhinolaryngology, Chungbuk National University Hospital, Cheongju, Korea \\ 'Department of Audiology \& Speech-Language Pathology, Daegu Catholic University, Gyeongsan, Korea \\ ${ }^{d}$ Department of Otorhinolaryngology-Head and Neck Surgery, Chungbuk National University College of Medicine, Cheongju, Korea
}

Correspondence: Dong-Wook Lee, MD, PhD Department of Otorhinolaryngology-Head and Neck Surgery, Chungbuk National University, College of Medicine, 776 1(il)sunhwan-ro, Heungdeok-gu, Cheongju 28644, Korea Tel: $+82-43-269-6150$

Fax: +82-43-269-6609

E-mail: dwlee@chungbuk.ac.kr

Received: April 5, 2019

Revised: May 19, 2019

Accepted: June 9, 2019

\begin{abstract}
Objectives: There are multidisciplinary and collaborative approaches for management of benign vocal fold lesions. Laryngeal microsurgery is one of the management procedures for treatment of dysphonia with medication and voice therapy. Laryngeal microsurgery, in particular, has been implemented when there is no vocal improvement after medication or voice therapy. However, voice problems often persist following surgery. The aim of this study was to investigate the effect of voice therapy in the treatment of postoperative functional dysphonia. Methods: Indirect and direct voice therapy consisting of laryngeal massage and semi-occluded vocal tract exercises (SOVTE) were performed on 14 female patients with dysphonia. Auditory-perceptual, acoustic analysis and the Korean version of Voice Handicap Index-10 (K-VHI-10) were compared before and after voice therapy. Results: In acoustic analysis, standard deviation of FO (STD), Jitter, pitch perturbation quotient (PPQ), fundamental frequency variation (vF0), Shimmer, amplitude perturbation quotient $(\mathrm{APQ})$, peak to peak amplitude variation (vAm), noise-to-harmonic ratio (NHR), degree of sub-harmonic (DSH) were significantly lower after voice therapy. Significantly lower levels of 'grade', 'breathiness', and 'strain' in GRBAS were revealed following voice therapy. In addition, $\mathrm{K}-\mathrm{VHI}-10$ was also significantly reduced after voice therapy. Conclusion: SOVTE and laryngeal massage were effective for patients with persists dysphonia by modifying or eliminating inappropriate vocal patterns that lead to voice dysfunction. Therefore, voice therapy following laryngeal surgery can be useful to recover vocal fold functions that cannot be solved by voice rest or vocal hygiene alone.
\end{abstract}

Keywords: Laryngeal microsurgery, Dysphonia, Voice therapy, Wound healing
양성성대질환의 치료법은 음성치료와 외과적인 방법으로서 성 대의 병변을 제거하는 후두미세수술이 있다. 또한, 경구강(transoral) 또는 경피적(transcutaneous) 접근을 통해 스테로이드나 보 톡스 같은 물질을 성대 내에 주입하는 성대 내 주입술과 보조적인 수단으로서 스테로이드 제제, 점액용해제, 항생제, 양자펌프억제제 등을 복용하는 약물치료를 실시할 수 있다(Lee, 2015).

후두미세수술은 성대의 접촉을 방해하는 병변의 제거를 통해 성대 접촉면을 부드럽게 만들어 음질을 향상시키고 공기역학적 효 율성을 높이는 치료방법이다(Zeitels, 2000). 대부분의 양성성대질
환이 있는 환자는 음성장애를 호소하기 때문에, 수술적 치료는 무 엇보다 음성의 호전을 우선시하며 이를 위해 수술 전과 후 환자의 음성에 대한 정확한 평가와 분석이 실시된다(Petrovic-Lazic, Jovanovic, Kulic, Babac, \& Jurisic, 2011; Toran \& Lal, 2010). 후두미세 수술을 통한 양성성대질환의 치료는 음향학적 검사, 청지각적 평 가, 공기역학적 평가, 음성에 대한 환자의 주관적 평가 등 음성의 다 양한 측면에서 그 효과가 입증되어 왔다(Johns, Garrett, Hwang, Ossoff, \& Courey, 2004; Kang, Chang, \& Goo, 2016; Kim, Choi, \& Park, 2015; Shin et al., 2013). 
Behrman와 Sulica (2003)는 1,208명의 이비인후과 의사를 대상 으로 성대결절, 성대용종 및 낭종 수술 후음성휴식에 대해 조사하 였는데, $51.4 \%$ 는 절대적인 음성휴식을 권고한 반면, $62.3 \%$ 는 상대 적 음성휴식을, $15 \%$ 는 아무런 음성휴식도 전혀 권고하지 않은 것 으로 나타났다. 절대적 음성휴식을 위한 가장 일반적인 기간은 7일 이었는데 절대적 음성휴식 기간은 0-14일인 반면, 상대적 음성휴식 기간은 0-21일 이상이었으며, 양성성대병변의 질환에 따른 절대적 인 음성휴식과상대적인 음성휴식 사이에 유의미한 차이를 보이지 않았다.

Kim, Pyo, Choi, Kim과 Kim (1997)의 연구에서 후두미세수술 을 받은 양성성대 질환자의 $14 \%$ 가 성대반흔 $(33.3 \%)$, 재발성 병변 (16.7\%), 지속적인 염증반응(16.7\%), 잔류성 병변(16.7\%), 가성대의 과도한 수축(16.7\%) 등으로 인해 음성문제의 지속을 보고하였으 며, Shin 등(2013)의 연구에서는 후두미세수술을 받은 환자 중 $5.2 \%$ 에서 성대반흔(56.8\%), 잔류성 병변(21.6\%), 후두 부종의 지속 (13.5\%), 알 수 없음(13.5\%) 원인으로 인한 음성문제를 보고하였다. Woo, Casper, Colton과 Brewer (1994)의 연구에서도 성대반흔 (35.4\%), 재발성 병변(12.9\%), 지속적인 염증(20.9\%), 잔류성 병변 (6.4\%), 후두실과 성문 전후의 수축과 같은 기능적 음성장애 (11.3\%)로 인한 음성문제가 보고되었다.

일반적으로 칼과 같이 예리한 연장에 의한 상처(injury)를 의미 하는 창상(wounding)은 염증, 증식, 성숙의 세 단계를 통해 치유되 는데 후두미세수술 이후 성대 역시 이와 같은 치유과정을 거친다. 치유과정의 첫 번째 단계인 염증단계는 조직손상 후 3 일까지로 지 혈 및 염증 반응이 일어난다. 두 번째 단계인 증식단계에는 조직의 손상이 발생한 3 일 이후부터 1 개월까지로 혈관의 신생과 상피화가 진행된다. 마지막 단계인 성숙단계는 1년 이상 지속되며, 상처부위 의 조직이 재형성된다. 성대는 5 개의 다층 구조로 이루어져 있으며, 기능적으로는 상피층과 고유층의 표층이 덮개(cover)를 이루며, 근 육이 몸체(body)를 형성하는데 이 중 양성성대질환은 일반적으로 상피층과 고유층에만 영향을 준다. 후두미세수술의 목적은 병변 을 제거하고 반흔(scar) 없이 음질을 회복하는 것이 가장 이상적이 다. 반흔(scar)은 상처 조직의 불완전한 리모델링의 결과이며, 생체 역학적으로 정상적인 조직과는 다르다. 상처 치유과정에서 염증 반 응이 과도하게 일어날 때 미성숙한 교원질로 인하여 섬유화가 많이 발생하여 반흔이 형성된다(Ishikawa \& Thibeault, 2010).

후두미세수술로 인해 발생한 성대창상의 치유과정(wound healing)에서 수술 부위의 고유층(lamina propria)은 뻣뺏(stiffness)하 게 재생되고 손상이 없는 다른 부분의 정상적인 성대 조직에 비해 점탄성이 저하될 수 있다. 이와 같은 수술 부위의 반흔은 발성 동안
성대 진동에 영향을 주어 쉰 목소리, 음성 조절 상실, 음성피로로 이어진다(Benninger et al., 1996; Hansen \& Thibeault, 2006). 또한, 이러한 음성문제를 보상하기 위한 과도한 발성 노력은 후두의 과긴 장을 야기한다. 성대의 치료과정에서 메커니즘적 자극은 프로테오 글리칸 및 히알루론산의 발현 수준을 증가시키며, 섬유 아세포의 증식과 이동을 촉진할 뿐만 아니라 콜라겐 합성을 자극하고 섬유 가 운동방향으로 배열되어 조직의 회복에 유리하다. 따라서, 수술 후 3 일 후부터 시작되는 증식기 동안의 메커니즘적 자극은 상처 치 유과정에서 콜라겐 합성을 자극하고 적용된 힘의 방향으로 콜라겐 섬유를 정렬하는 데 도움이 될 수 있다(Ishikawa \& Thibeault, 2010).

반폐쇄성도훈련(semi-occluded vocal tract exercises, SOVTE)은 성도의 일부를 수축하는 것으로, 성도의 앞 혹은 뒤의 반폐쇄는 성 문상압이 성문내부의 압력과 기류를 증가시키도록 만들어 성도가 주파수에 해당하는 음들을 선택하여 강화시키는 전통적인 여과기 의 역할을 하는 것이 아니라 음원과 여과기 사이의 상호작용을 통 해 더 많은 공기역학적 에너지를 음향학적 에너지로 변화시키도록 감각 피드백의 역할을 한다는 비선형 음원-여과기 이론으로 설명 된다(Choi, 2017; Titze, 2006). SOVTE는 성도에서 진동하는 진동 원의 수에 따라 크게 단일 진동원(손으로 입가리기, 허밍, 빨대발 성)과 이중 진동원(물에 튜브를 넣어 발성 또는 입술트릴, 혀트릴) 으로 나눌 수 있으며, 그중에서 이중 진동원을 가진 훈련은 성대 진 동을 조절하고 성도에 마사지 효과를 주는 것으로 알려져 있다 (Andrade et al., 2014). 그뿐만 아니라, 구강 좁힘으로 인한 반폐쇄 로 인해 입 뒷부분의 구강내압이 증가하여 성대가 약간 외전된 상 태가 되기 때문에 발성 시 성대에 가해지는 충격이 최소화되는 효 율적인 음성훈련방법이다(Berry et al., 2001; Titze, 2006). 후두마사 지는 후두내외근을 포함한 성도 전체에 영향을 미칠 수 있는 후두 근육의 과긴장을 이완에 효과적인 방법이다(Aronson, 1990; Kim, Lee, Choi, \& Choi, 2017; Lee \& Son, 2005; Lieberman, 1998; Roy, Bless, Heisey, \& Ford, 1997; Van Lierde, De Ley, Clement, De Bodt, \& Van Cauwenberge, 2004).

메타인지는 인지적 과제 수행에 영향을 미치는 요소들에 대한 자신의 지식이나 생각을 의미하는 것으로 '아는 것과 그 앎에 대하 여 알고 있는 것을 아는 것’이라고 정의할 수 있다. 인지가 어떤 과제 를 수행하기 위한 지적인 활동이라면 메타인지는 과제의 처리를 위 한 모니터링 활동이며(Flavell, 1979), 인지가 어떤 것에 대한 이해나 이해하는 상태를 의미하는 것이라면 메타인지는 어떤 것에 대한 학습이나 이해를 넘어 어떻게 배울 것인지를 알고 있는 상태를 의 미한다(Senemolu, 2005). Kim, La와 Lee (2016)에 의하면 메타인지 는 인지적 지식(knowledge about cognition)과 인지적 조절(moni- 
toring of cognition)로 구분할 수 있는데, 인지적 조절의 '계획하기' 는 읽기 과제수행 전 전략을 세우고 시간이나 주의를 선택적으로 할당하는 것처럼, 적절한 전략의 선택과 성과에 영향을 미치는 자 원의 할당을 의미한다. '모니터링 혹은 조절하기'는 학습하는 동안 스스로 테스트하는 능력과 같이 과제수행과 이해하는 것에 대한 인식을 의미하는 것으로, 훈련이나 실습을 통해 향상될 수 있는 활 동이며, 마지막으로 ‘평가하기'는 계획하기와 같은 메타인지나 조절 능력과 관련된 것으로 학습과정에서 나타난 자신의 조절과정과 결 과물을 평가하는 것을 의미한다.

이에 따라 본 연구는 성대결절이나 성대폴립로 인해 후두미세수 술을 받은 환자 중 성대에 기질적인 문제는 없으나 음성문제의 지 속을 호소하는 환자를 대상으로 SOVTE와 후두마시지를 이용한 음성치료에 메타인지를 적용한 음성치료법의 효과를 알아보고자 한다.

\section{연구방법}

\section{연구대상}

본 연구의 대상자는 2016년과 2017년 충북대학교병원 후두미세 수술을 받은 환자 중 이비인후과 전문의에 의해 성대의 기질적 문 제는 없으나 지속적인 음성문제를 호소하는 환자 12 명과 같은 이유 로 타 대학병원에서 후두미세수술을 받고 내원한 2명 총 14명이다. 대상자는 모두 여성이고 평균연령은 46.5세이며, 수술 후 음성을 전혀 사용하지 않는 완전한 음성휴식 기간은 평균 4.79일(범위 3-12일)이었다. 수술 후 평균 14.36일(범위 10-23일) 후 음성평가를 받았고, 평균 9일 간격(범위 2-21일)으로 1 회 30분의 음성치료를 평 균 2.29회(범위 2-4회) 받았다. 수술 후부터 종결까지 소요된 기간 은 평균 27.2일(범위 13-56일)이었다(Table 1).

\section{음향학적 분석}

연구자는 마이크와 입과 약 $10 \mathrm{~cm}$ 의 거리를 두고 음성치료 전과 후 소음이 통제된 환경에서 환자에게 편안한 강도와 음도에서 모음 $/ \mathrm{a} /$ 를 연장발성을 하도록 하였다. 샘플링된 음성의 분석은 $\mathrm{a} /$ 연장

Table 1. Participants' information

\begin{tabular}{lccc}
\hline Diagnosis & Age $(\mathrm{yr})$ & $\begin{array}{c}\text { Perfect voice } \\
\text { rest (day) }\end{array}$ & $\begin{array}{c}\text { Voice therapy } \\
\text { (freq) }\end{array}$ \\
\hline Vocal fold nodules ( $\mathrm{N}=7)$ & $41.11 \pm 7.93$ & $4.86(3-7)$ & $2.14(2-3)$ \\
Vocal polyp ( $\mathrm{N}=7)$ & $51.89 \pm 5.00$ & $4.71(3-12)$ & $2.43(2-4)$ \\
Total $(\mathrm{N}=14)$ & $46.50 \pm 8.48$ & $4.79(3-12)$ & $2.29(2-4)$ \\
\hline
\end{tabular}

Values are presented as mean $\pm \mathrm{SD}$ or mean (range).
발성 중 안정구간 1 초를 선택하여 Kay PENTAX사에서 개발한 Multispeech 3.7의 Multi-Dimensional Voice Program (MDVP)을 이용하여 실시하였다(Ko, 2015). 분석된 변수는 기본주파수 관련 변수 average fundamental frequency (F0), standard deviation of F0 (STD), jitter percent (\%)itter), pitch perturbation quotient (PPQ), fundamental frequency variation (vF0)과음성강도 관련 변수 shimmer percent (\%Shimmer), amplitude perturbation quotient (APQ), peak to peak amplitude variation (vAm), 진전 관련 변수 F0 tremor intensity index (FTRI), amplitude tremor intensity index (ATRI), 잡음 관련 변수 noise-to-harmonic ratio (NHR), voice turbulence index (VTI), sub-harmonic 관련 변수 degree of sub-harmonic (DSH), degree of voiceless (DUV)이며, 치료 전후 음향학적 차이를 비교하였다.

\section{청지각적 평가}

GRBAS 척도를 활용하여 음성치료 전과 후 환자의 /a/모음 연장 발성을 듣고 청지각적 평가를 실시하였다. 청지각적 평가의 신뢰도 확인을 위해 연구자 외에 이비인후과 음성장애 임상경험 5년 이상 인 1 급 언어재활사 1 명이 수집된 녹음자료를 무작위로 듣고 각각 청지각적 평가를 하였다. 검사-재검사 신뢰도 측정을 위해 음성샘 플 28개 중 무작위로 추출한 25\%를 평가하였다. Grade, Rough, Breathy, Asthenic, Strained (GRBAS)의 검사-재검사 신뢰도는 연 구자는 $100 \%, 100 \%, 100 \%, 100 \%, 93 \%$ 였으며 검사자 2는 $93 \%$, $100 \%, 93 \%, 100 \%, 100 \%$ 이었으며, 다른 임상가와 연구자 간의 $\mathrm{GRBAS}$ 의 검사자 간의 신뢰도는 각각 $100 \%, 100 \%, 93 \%, 100 \%$, 93\%이었다. GRBAS 점수가 두 검사자 간 일치하지 않는 경우는 협 의하여 최종측정하였다.

\section{음성장애지수}

음성장애지수(Voice Handicap Index, VHI)는 대상자가 경험하 는 음성장애가 일상생활에 미치는 정도를 환자가 신체적, 기능적 및 감정적 측면에서 평가하는 것으로, 총 30 문항으로 구성되어 있 으며 각 문항을 5 점척도로 평가한다. 본 연구에서는 시간 경제성 및 효용성을 위해 VHI-10의 한국판 버전인 K-VHI-10 (Yun, Kim, Son, \& Choi, 2008)을 사용하였다.

\section{음성치료프로그램 \\ 후두 마사지}

후두마사지는 설골 뒤편, 갑상연골막 앞쪽, 갑상연골 뒤쪽 융기 와 설골상근 및 설골하근 촉진 후 실시하였다. 후두마사지 순서는 
흥쇄유돌근과 설골상근 및 설골하근, 설골과 갑상연골 사이 갑상 연골막 앞쪽의 순서로 진행하였다. 흥쇄유돌근은 쇄골에서 유양돌 기방향으로 마사지 실시 후 다시 쇄골쪽으로 양쪽 각각 실시하였으 며, 설골 뒤편과 설골상근 및 하근은 엄지와 검지로 원을 그리듯 안 에서 밖으로, 밖에서 안으로 마사지하였다. 다음으로 갑상연골 대 각(superior horn) 주변을 엄지를 이용하여 양쪽 각각 원을 그리듯 마사지 후 엄지와 검지로 다시 양쪽을 동시에 마사지하였다. 갑상설 골막 앞쪽은 먼저 엄지와 검지를 이용해 밖에서 안으로 마사지 후 갑상연골 대각을 아래로 살짝 누른 후 환자가 턱을 서서히 위쪽으 로 들게 하였다. 이후 엄지와 검지를 이용해 갑상연골을 아래 쪽으 로 충분히 하강시켰다. 마지막으로, 엄지를 이용해 갑상연골을 각 각 좌측과 우측으로 민 상태에서 심호흡하도록 하였다. 각 부분을 전체적으로 마사지하되 과긴장이 관찰된 부분은 보다 더 집중적으 로 마사지를 실시하였다. 마사지 전 환자에게 “꽃 향기 맡듯이 가볍 게 코로 숨을 들이쉬고, 내쉴 때는 약 바른 상처에 바람을 불 듯이 길고 천천히 부드럽게 하세요”라고 주의를 준 후, 호기 시에만 한 손을 사용하여 후두마사지를 실시하였으며, 총 소요시간은 7-10분 내외였다(Kim et al., 2017). 후두마사지는 매 세션 후두의 과긴장 유무를 평가하고 실시하였으며 후두의 과긴장이 관찰되지 않는다 면 더 이상 실시하지 않았다.

\section{반폐쇄성도운동}

반폐쇄성도운동(SOVTE)은 SOVTE의 다양한 방법들 가운데 빨대발성, 입술트릴, 비강자음을 이용한 허밍발성, 양순유성마찰 음[ㅂ:]을 각각 1-2분씩 진행하였다. 연구자는 환자에게 모델링을 제시하고 환자가 이를 모방하도록 하였다. 빨대발성은 물과 빨대 혹은 튜브를 사용하는 Lax Vox가 아니라 오직 직경 $0.5 \mathrm{~cm}$, 길이 $17.8 \mathrm{~cm}$ 사이즈의 빨대만을 사용하여 음도 상승과 하강, 연장발성 두 가지의 형태로 gliding이나 scaling을 통해 음도 상승과 하강을 실시한 후 G2 $(98 \mathrm{~Hz})$ 와 C3 $(130 \mathrm{~Hz}), \mathrm{G} 3(195 \mathrm{~Hz}), \mathrm{C} 4(260 \mathrm{~Hz}), \mathrm{E} 4$ $(329 \mathrm{~Hz})$ 에서 각각 반폐쇄성도운동으로 연장발성하도록 하였다. 예를 들면, 여성의 경우 허밍발성으로 G3 $(195 \mathrm{~Hz})$ 에서 gliding과 scaling으로 음도 상승과 음도 하강을 반복적으로 실시하고 이후 C3 $(130 \mathrm{~Hz}), \mathrm{G} 3(195 \mathrm{~Hz}), \mathrm{C} 4(260 \mathrm{~Hz}), \mathrm{E} 4(329 \mathrm{~Hz})$ 에서 각각 음도 변화 없는 허밍 연장발성을 실시한다(남성의 경우 C3에서 gliding 이나 scaling 실시 후 G2, C3, G3, C4에서 연장발성 실시함). 이와 같은 방법으로 입술트릴과 빨대발성, 양순유성마찰음[ㅂ: 도 동일 하게 실시하였는데, 허밍 시에는 충분히 공명될 수 있도록 구강과 인두강 확장과 함께 원순모음/기의 포즈를 유지하도록 하였으며, 양순마찰음[ㅂ:]은 '뱃고동 소리’를 내는 것과 유사한 것이라고 먼
저 설명하고, 대상자가 하인두의 팽창을 지각하고 유지하도록 하였 다. 반폐쇄 성도운동 시 연장발성의 후반부에 나타나는 상복근의 수축감과 허밍발성나 양순마찰음[ㅂ:] 발성 시 나타나는 안면의 공 명감에 집중하도록 함으로써 환자들이 감각에 대한 충분히 지각 을 할 수 있도록 유도하여 더 정확하고 쉽게 반폐쇄성도운동 과제 를 수행할 수 있도록 하였다. 음성치료에 있어 반폐쇄성도운동 시 이와 같은 감각지각은 수술 후 환자에게 남아있는 발성기관의 과긴 장이나 반폐쇄성도운동을 환자가 잘못된 방법으로 수행하는 것을 예방하기 위해서이다(Kim et al., 2017).

\section{음성행동 조절을 위한 메타인지 적용}

메타인지를 활용해 음성오남용 조절과 습윤관리 등 음성위생의 준수와 치료세션에서 실시했던 SOVTE를 환자 스스로 수행할 수 있도록 하였다. 연구자는 대상자가 매일 밤 자신의 음성오남용을 포함한 음성위생과 SOVTE와 같은 ‘음성행동’의 수행 여부를 스스 로 평가(evaluation)하고, 이를 토대로 '출근길 운전할 때 SOVTE 수행하기, 회의시간에 커피 마시지 않기, 사무실 환기하기' 등과 같 이 다음 날의 음성행동을 계획(planning)하도록 하였다. 또한 일상 에서 '내가 목소리를 오용한 건 아닌가?', '수분 섭취는 충분히 하고 있나?'와 같이 실시간으로 자신의 음성행동을 스스로 모니터링 (monitoring)하고 그 결과에 따라 자신의 음성행동의 수행을 줄이 거나 늘리기 위한 조절(regulation)을 하도록 하였다. 인지적 단서에 기반한 이러한 음성행동의 조절은 정서적 신체적 조건에 따라 수행 이 저하되거나 수행 자체를 잊어버릴 수 있다는 점(Vinney \& Turkstra, 2013)을 고려하여 연구자는 대상자의 일상 생활환경에 스티커 를 붙이도록 하여 인지적 점화가 일어나도록 하여 음성행동의 수행 을 촉진하였다.

\section{통계분석}

수집한 자료를 통해 본 연구에서 실시한 음성치료의 효과를 확 인하기 위해 음성치료 전후의 음향학적 검사와 청지각적 평가 결과 의 차이를 비교하기 위해 SPSS (Statistics Package for the Social Science version 21.0; IBM, Armonk, NY, USA)를 이용하여 Wilcoxon signed-ranks test를 실시하였다. 통계적 유의수준은 $95 \%$ 수 준에서 검증하였다.

\section{연구결과}

음성치료 전과 후 음향학적 검사 결과 측정치 비교

$\mathrm{MDVP}$ 를 이용하여 음성재활 치료 전후 실시한 음향학적 검사의 
Table 2. Comparisons of acoustic measures before and after voice rehabilitation therapy

\begin{tabular}{lccc}
\hline & Before & After & Z \\
\hline Fo & $201.435 \pm 20.01(205.240)$ & $204.875 \pm 12.07(205.839)$ & -.596 \\
STD & $7.183 \pm 14.26(2.946)$ & $1.907 \pm 0.91(1.761)$ & $-2.731^{* *}$ \\
\%Jitter & $1.804 \pm 1.40(1.467)$ & $0.721 \pm 0.46(0.584)$ & $-3.107^{* *}$ \\
PPO & $1.12 \pm 0.95(0.906)$ & $0.421 \pm 0.27(0.334)$ & $-3.107^{* *}$ \\
$\%$ Shimmer & $8.22 \pm 2.44(7.985)$ & $4.256 \pm 1.44(0.744)$ & $-3.296^{* * *}$ \\
APO & $5.70 \pm 1.64(5.678)$ & $3.013 \pm 0.85(4.141)$ & $-3.296^{* * *}$ \\
vFo & $3.883 \pm 8.10(1.336)$ & $0.901 \pm 0.43(3.198)$ & $-2.794^{* *}$ \\
vAm & $12.465 \pm 3.93(11.407)$ & $7.259 \pm 1.70(7.046)$ & $-2.919^{* *}$ \\
NHR & $0.179 \pm 0.05(0.158)$ & $0.132 \pm 0.01(0.133)$ & $-3.297^{* * *}$ \\
VTI & $0.060 \pm 0.02(0.595)$ & $0.052 \pm 0.01(0.52)$ & -1.153 \\
FTRI & $0.349 \pm 0.41(0.268)$ & $0.206 \pm 0.21(0.227)$ & -.889 \\
ATRI & $2.623 \pm 2.80(1.987)$ & $1.306 \pm 1.44(0.854)$ & -1.153 \\
DSH & $5.077 \pm 7.52(1.352)$ & $0.325 \pm 1.21(0)$ & $-2.366^{*}$ \\
DUV & $3.123 \pm 7.91(0)$ & $0(0)$ & -1.826 \\
\hline
\end{tabular}

Values are presented as mean $\pm S D$ (median).

${ }^{*} p \leq .05,{ }^{* *} p \leq .01,{ }^{* * *} p \leq .001$.

결과는 Table 2 와 같다. 기본 주파수 $\left(\mathrm{F}_{0}\right)$ 의 평균은 수술 전 201.4354 $\mathrm{Hz}$ 에서 수술 후 $204.875 \mathrm{~Hz}$ 로 증가하였으며 기본주파수의 표준편 차(STD)는 치료 전 $7.183 \mathrm{~Hz}$ 에서 치료 후 $1.907 \mathrm{~Hz}$ 로 감소하였다. 주파수변동률(Jitter)은 치료 전 $1.804 \%$ 에서 치료 후 $0.721 \%$ 로 감소 하였으며, 장단기 주파수 변이에 해당하는 $\mathrm{PPQ}$ 는 치료 전 $1.12 \%$ 에 서 치료 후 $0.421 \%$ 로 감소하였다. 강도변동률(\%Shimmer)은 치료 전 $8.22 \%$ 에서 치료 후 $4.256 \%$ 로 감소하였으며, 장단기 강도변이에 해당하는 $\mathrm{APQ}$ 는 치료 전 5.7\%에서 치료 후 $3.013 \%$ 로 감소하였다. $\mathrm{vFo}$ (기본주파수 변이)는 치료 전 $3.883 \%$ 에서 치료 후 $0.901 \%$ 로 감 소되었으며, $\mathrm{vAm}$ (강도변이)는 치료 전 $12.465 \%$ 에서 치료 후 $7.259 \%$ 로 감소하였다. 비정상배음의 비율을 반영하여 음성의 전반적 잡 음을 설명하는 NHR (소음대 배음비)은 치료 전 0.179 에서 치료 후 0.132 로 감소되었으며, VTI (고주파 잡음대 소음비)는 치료 전 0.060 에서 치료 후 0.052 로 감소되었다. FTRI (기본 주파수 진전)는 치료 전 $0.349 \%$ 에서 치료 후 $0.206 \%$ 로 감소되었으며, ATRI (음성강도 진전)는 치료 전 $2.623 \%$ 에서 치료 후 $1.306 \%$ 로 감소되었다. DSH (이중음성 정도)는 치료 전 5.077에서 치료 후 0.325 로 감소되었으 며, 전체 음성샘플에서 기본주파수가 측정되지 않는 non-harmonics이 나타나는 길이 비율을 나타내는 DUV (무발성 정도)는 치료 전 3.123에서 치료 후 0 으로 감소되었다. 이러한 음향학적 변수들 가운데 $\operatorname{STD}(p=.006)$, Jitter ( $p=.002), \mathrm{PPQ}(p=.002), \mathrm{vF0}$ ( $p=.005)$, Shimmer ( $p=.001), \mathrm{APQ}(p=.001), \operatorname{vAm}(p=.004), \operatorname{NHR}(p=.001)$, $\operatorname{DSH}(p=.018)$ 는 치료 전과 후에서 유의한 차이가 있었다.
Table 3. Comparisons of auditory-perceptual measures before and after voice therapy during /a/ sustained vowel phonation

\begin{tabular}{lccl}
\hline & \multicolumn{1}{c}{ Before } & After & \multicolumn{1}{c}{ Z } \\
\hline Grade & $1.571 \pm 0.51(2.000)$ & $0.643 \pm 0.50(1.000)$ & $-2.739^{* *}$ \\
Rough & $0.357 \pm 0.50(0.000)$ & $0.143 \pm 0.36(0.000)$ & -1.732 \\
Breathy & $1.071 \pm 0.61(1.000)$ & $0.214 \pm 0.43(0.000)$ & $-3.207^{* * *}$ \\
Asthenic & $0.214 \pm 0.43(0.000)$ & $0.000(0.000)$ & -1.732 \\
Strained & $0.643 \pm 0.50(1.000)$ & $0.000(0.000)$ & $-3.000^{* *}$ \\
\hline
\end{tabular}

Values are presented as mean $\pm S D$ (median).

${ }^{*} p \leq .05,{ }^{* *} p \leq .01,{ }^{* * *} p \leq .001$.

Table 4. Comparisons of K-VHI-10 measures before and after voice therapy

\begin{tabular}{cccc}
\hline & Before & After & Z \\
\hline K-VHI-10 & $17.143 \pm 10.14(16.500)$ & $6.429 \pm 7.29(3.500)$ & $-3.182^{* * *}$ \\
\hline
\end{tabular}

Values are presented as mean \pm SD (median).

$\mathrm{K}-\mathrm{VHI}-10=$ Korean version of Voice Handicap Index-10.

${ }^{*} p<.05,{ }^{* *} p<.01,{ }^{* * *} p<.001$.

\section{음성치료 전과 후 청지각적 평가 결과 측정치 비교}

$\mathrm{GRBAS}$ 를 이용하여 음성치료 전과 후의 청지각적 평가를 비교 한 결과는 Table 3과 같다. Grade 척도는 치료 전 1.571 (G2 5명, G1 9명)에서 치료 후 0.643 (G1 9명)으로, Rough 척도는 치료 전 0.357 (R1 5명)에서 치료 후 0.143 (R1 2명)으로, Breathy 척도는 치료 전 1.071 (B2 4명, B1 9명)에서 치료 후 0.214 (B1 3명)로, Asthenic 척도 는 치료 전 0.214 (A1 3명)에서 치료 후 0으로, Strained 척도는 치료 전 0.643 (S1 8명)에서 0 으로 감소하였다. 이 가운데 Grade ( $p=.006)$ 와 Breathy ( $p=.001)$, Strained ( $p=.003)$ 는 치료 전과 후 유의한 차 이가 나타났다.

\section{음성치료 전과 후 음성장애지수 측정치 비교}

Table 4에 나타난 바와 같이 K-VHI-10은 치료 전 17.143이었던 것에 비해 치료 후 6.429 로 모두 유의하게 감소 $(p=.001)$ 된 것으로 나타났다.

\section{논의 및 결론}

음성장애는 사회적 의사소통에 영향을 주고 삶의 질에 영향을 미치는 가장 일반적인 의사소통장애 중 하나이다. 수술 후 음성재 활과 관리로는 음성휴식, 음성위생, 음성치료가 권고된다(Choi, 2019). 수술 후 잘못된 목소리 사용은 성대 점막 조직에 반흔을 초 래하며, 성대반흔은 성대 조직의 유연성을 저하시키며 점성(viscosity) 증가로 인하여 음성 회복에 제한적이다. 따라서 반흔의 예방과 점막의 치유를 촉진하기 위하여 음성휴식이 처방된다(Benninger 
et al., 1996; Ishikawa \& Thibeault, 2010).

수술 후 음성휴식은 수술 후 성대 상처의 악화를 예방하기 위해 가장 흔히 사용되는 방법이다(Kaneko et al., 2017). 하지만 음성휴 식에 대한 정해진 표준 기준이 부재하고 음성휴식 기간이 임상가마 다 차이가 있다. 최근 양성성대질환에 대한 수술 직후 음성외과의 에 의해 시행된 음성휴식의 기간을 조사한 결과, 성대결절, 성대용 종, 라인케부종에 대해서는 완전한 음성휴식은 7일이 가장 많았으 며, 백반증과 유두종은 1-4일이었고, 대부분의 병변에 대해서는 8 일 동안 상대적인 음성휴식을 취하도록 권고하였다. 이러한 음성휴 식에 대한 변이성은 수술 후 음성 개선 효과를 지지하는 데 제한이 있다(Joshi \& Johns, 2018). 한편, 정형외과 재활에서는 휴식과 운동 간에 논쟁의 여지가 있어 왔는데, 수술 부위의 고정(immobilization)은 상처가 치유되는 동안 직감적으로는 이로울 것으로 보이지 만, 최근 한 연구에 의하면 관절의 자유로운 지나친 움직임은 기능 적 회복에 좋지 못한 결과를 초래하지만 치유의 초기 과정에서 통제 된 재움직임(remobilization)은 기능적 회복에 도움을 주는 것으로 나타났다(Frank, 1996; Inoue et al., 1990). 따라서, 장기간 동안 움직 이지 않는 것은 근육과 뼈의 위축(atrophy)뿐 아니라 결합 조직의 변 형을 가져와 오히려 기능적 회복에 해로운 것으로 간주되었다.

양성성대질환 후두미세수술의 경우, 대부분 수술 후의 음성재 활이 음성휴식이나 음성위생에 그치는 경우가 많으나, 최근 상처 치유를 개선하기 위한 방법으로 조기 성대 자극이 권고되고 있다. Culav, Clark과 Merrilees (1999)와 Ishikawa와 Thibeault (2010)에 의하면 초기 성대 치유과정에서 성대에 자극이 과도하면 조직을 비 대하게 만들어 흉터를 유발하거나 탄성이 감소될 수 있지만, 상처 에 가해지는 적절한 긴장은 섬유아세포 활동(fibroblast activities) 을 촉진시켜 콜라겐 합성을 자극하고 적용된 힘의 방향으로 콜라 겐 섬유를 정렬하여 최적의 조직 회복을 촉진할 수 있다고 하였다. 또한, Branski, Verdolini, Sandulache, Rosen과 Hebda (2006)는 수 술 후 일정한 음성휴식 후 성대 근육의 움직임은 세포외기질(matrix)의 합성을 증가시키기 때문에 수술 후 상처가 치유되는 동안 성대 염증을 감소시키고 또한, 세포외기질(matrix)의 합성을 증가 시키기 때문에 수술 후 적절한 성대 운동은 성대를 전혀 움직이지 않는 음성휴식보다 성대의 상처 치료에 도움을 준다고 하였다. Abbott 등(2012)의 연구에 의하면, 1 시간 동안 발성을 지속하여 급성 음성외상이 발생한 9명의 대상자에게 음성휴식, 보통과 같이 말하 기, 공명발성운동의 세 가지 중재 방법 중 하나의 집단에 무작위 배 치 후 24 시간 후 성대에서 조직 외상의 항염증 매개자인 항염증 사 이토카인 IL-1 $\beta$, IL-6, and MMP-8 유전자 발현 정도와 발성역치압 력(phonation threshold pressure, PTP)의 상관성을 살펴보았다. 연
구 결과, 공명발성이 가장 좋은 결과를 나타내었으며 이는 음성휴 식보다 음성치료에 의한 조직 움직임이 성대 염증을 감소시키는 데 도움을 준다고 하였다. 또한, 장기간 조직의 부동화(immobilization)는 상처 회복에 해로운 것으로 나타났으며 적절한 성대 운동 이 성대의 세포외기질의 중요한 세포인 섬유아세포(fibroblast)를 자극하여 조직항상성(tissue homeostasis)을 유지하고 성대의 세포 외기질(extracellular matrix, ECM)을 재조직화하는 데 매우 중요 한 역할을 한다고 하였다.

현재까지 수술적 중재나 행동적 중재가 음성장애를 치료하기 위 한 목적으로 시행되고 있으나, 음성 외과수술 중재는 성대반흔(vocal fold scarring)의 가장 일반적 원인 중 하나이며 비일관적인 음 성 개선을 초래하기도 한다(Benninger et al., 1996; Hansen \& Thibeault, 2006). 성대반흔은 성대 손상 후 나쁜 음성을 초래하는 가 장 큰 원인으로서 성대반흔은 성대 고유층의 점탄성에 영향을 주 고 성대의 진동 부위를 뻣뻣하게 하며 성문폐쇄부전의 원인이 된다 (Hansen \& Thiebeault, 2006). 특히, 수술 후 유발되는 성대 반흔은 성대의 세포외기질(ECM)을 구성하고 있는 요소들의 밀도나 조직 화 형태를 변화시켜 성대의 생체역학적(biomechanical) 특성에 영 향을 주어 발성 동안 성대 진동을 방해한다. 또한, 후두미세수술 전 잘못된 발성 습관이나 오남용 패턴들이 수술 후에도 여전히 남아 있어 병변 제거 후에도 음성에 나쁜 영향을 줄 수 있다.

본 연구는 성대결절과 성대폴립으로 인해 후두미세수술을 받고 성대의 점막파동을 방해하는 종물을 제거하였으나 음성문제가 지 속된다고 호소하는 대상자들에게 후두마사지와 SOVTE를 적용한 음성치료를 실시하고, 그 효과를 알아보기 위해 치료 전과 후 음성 평가 결과를 비교하였다. 본 연구의 대상자들은 음성치료를 실시 한 후 성대의 주기성과 관련된 음향학적 변수인 \%Jitter, PPQ, $\%$ Shimmer, $\mathrm{APQ}, \mathrm{NHR}$ 과 호흡발성 조절과 관련된 변수인 $\mathrm{vF0}$, $\mathrm{vAm}, \mathrm{DSH}$ 가 수술 전에 비해 유의하게 감소하였다. 청지각적 평가 에서는 수술 후 ' $\mathrm{G}$ ' 척도가 1.571 에서 치료 후 0.643 으로 감소하였 고, 'B' 척도와 ' $\mathrm{S}$ '척도 역시 1.071에서 0.214로, 0.643 에서 0 으로 감 소하였다. VHI-10 도 17.143점에서 6.429점으로 10점 이상 감소하며 대상자가 주관적으로 느끼는 음성 또한 개선된 것으로 나타나 본 연구에서 실시한 치료프로그램의 효과를 확인할 수 있었다.

허밍발성 시 피열후두개주름과 피열연골 상단이 고딕아치 형태 를 이루며 성문 상부의 근긴장을 이완시키고, 부드러운 성대폐쇄 함께 폐쇄 시 성대의 형태가 성대점막파동이 충분히 이루어질 수 있는 상태가 된다(Harris, 1998). 또한, Ogawa 등(2014)의 연구에서 는 허밍발성이 성대 진동의 규칙성을 조절하고, 성문접촉을 증가시 키며 청지각적 음질과 성대의 주기성을 향상시켰다. 입술트릴, 튜브 
발성 같은 SOVTE는 Guzman 등(2013)의 연구와 Dargin, DeLaunay와 Searl (2016)의 연구에서 성대의 진폭과 점막파동을 증가시 키고 하인두와 성문 전후의 압축을 이완하며 후두의 위치를 하강 시키는 것으로 보고되었다. 양순파열음[ㅂ:]은 빨대발성의 전신으 로 구강을 통과하는 기류를 증가시키고 허밍과 같이 성도의 앞부 분을 좁혀 입 뒤쪽 압력인 구강압을 증가시켜 허밍과 동일한 효과 를 가져온다(Kim et al., 2017; Laukkanen, Lindholm, Vilkman, Haataja, \& Alku, 1996). 또한, 후두미세수술 이후 음성치료에 허밍 발성을 적용한 Ju 등(2013)과 빨대발성을 적용한 Kaneko 등(2017) 의 연구에서 음성장애지수와 청지각적 음성이 개선되고 음향학적 변수가 감소되었는데 본 연구는 성도의 수축을 기본으로 하는 SOVTE를 사용했다는 점에서 이러한 선행연구들과 그 결과가 일 치한다고 볼수 있다.

Menezes 등(2011)의 연구에서 트릴 5 분간 수행 시 청지각적으로 조조성, 기식성이 감소되고 전반적인 음질이 향상되었지만, 7 분은 긴장감 증가와 같은 부정적 반응이 나타났다. 이를 토대로 본 연구 에서는 회기 중 허밍발성, 입술트릴, 양순파열음[ㅂ:]을 5 분 미만으 로 실시하도록 조절하였다. 또한, 일상에서 대상자 스스로가 1 회당 1-5분 미만으로 실시하되 한두 시간에 한 번 정도 수행하도록 권고 하여 안정된 성대 진동의 주기성과 점막파동이 지속적으로 유지되 도록 하였다.

Behrman와 Sulica (2003)에 의하면, 수술 후 음성휴식 기간은 매우 다양하였으며, 음성휴식에 관한 근거가 있는 확립된 표준 프 로토콜은 없었다. 최근 한 연구에서는 최적의 음성휴식 기간을 조 사하기 위하여 수술 후 서로 다른 음성휴식 시간을 적용한 후 음성 치료를 실시한 결과, 7일보다 3일 음성휴식 후 음성치료를 받은 집 단이 \%jitter, \%Shimmer, GRBAS 및 VHI-10의 결과가 더 유의미하 게 개선되었다. 따라서, 현재 임상에서 주로 사용하는 1 주일 음성휴 식보다는 3 일 후 음성치료가 가장 좋은 음성 개선을 나타내었다 (Kaneko et al., 2017). 본 연구에서 음성휴식 기간은 1주일을 권고하 였지만 대상자들은 평균 4.79일 절대적인 음성휴식을 취하였으며, 대상자 대부분이 수술 후 평균 2주(범위 10-23일) 후 병원에 내원하 여 음성평가를 받았는데, 후두내시경 검사 결과, 성대 병변은 모두 제거되었으나 대상자 대부분은 병변이 제거된 성대의 점막파동이 거의 없고 병변이 없었던 반대쪽 성대의 움직임만이 주로 관찰되어 비대칭적이거나 비주기적인 진동 양상을 보였다. 이러한 현상은 음 성수술 후 병변이 제거되었지만 상처가 리모델링되는 과정에서 정 상 성대 조직과는 달리 성대 점막이 뻣뻣해지고 유연성이 감소하여 성대의 진동에 영향을 준 것으로 보인다. 이는 수술 후 성대의 구조 적인 문제는 없어 보이나 여전히 성대 기능의 문제는 남아 있어 수
술 후 일정 기간 음성휴식 후 적절한 성대 운동이 필요함을 시사한 다. 본 연구에서도 대상자 모두수술 후 병변 제거 후음성문제를 보 였으나, 후두마사지와 SOVTE 음성치료 후 음질이 개선되고 성대 진동이 개선되는 효과를 나타내어 수술 후 음성치료가 성대의 기 능 회복에 매우 중요함을 시사하였다. 이는 단순히 수술이나 음성 위생만으로는 성대 기능의 완전한 회복은 제한이 있음을 의미한 다. 본 연구의 대상자들은 성대 기능이 완전하진 않더라도 성대 진 동 주기성이 안정되고 청지각적 음성의 개선이 나타났을 때, 대상자 가 오남용 조절을 포함한 음성위생을 준수할 수 있고 치료 시 실시 한 SOVTE를 스스로 수행할 수 있다고 판단되는 경우 종결하였다. 또한, 메타인지를 음성치료에 적용하여 스티커를 통해 목표행동을 인지적으로 점화하고 그 수행을 촉진하였다.

본 연구에서 실시한 후두마사지와 SOVTE는 발성기관의 과긴장 을 이완하여 수술 후 회복과정에서 성대의 과도한 성대접촉을 예 방하며, 특히 음성치료방법 중 SOVTE는 성대가 받는 자극을 최소 화하면서도 부드러운 성대 진동과 안정적인 성대점막파동을 촉진 하여 성대 미세구조 조직의 회복을 촉진할 수 있는 방법이라고 할 수있다.

후두미세수술 이후 음성치료에 관한 선행연구를 살펴보면 단순 히 음성위생의 준수와 오남용 예방과 같은 간접적인 치료를 실시한 경우가 대부분이고, 직접적인 음성치료를 실시한 경우도 있었지만 어떤 방법으로 실시했는지 기술하지 않은 경우가 많았다(Béquignon et al., 2013; Petrovic-Lazic et al., 2015). 또한, '음성위생, 어깨 와 목의 이완, 허밍을 이용한 공명발성(Ju et al., 2013)' 혹은 '액센트 기법(Park et al., 2000)' 혹은 '빨대발성(Kaneko et al., 2017)'이나 Boone의 음성촉진기법 중 '근육이완, 호흡훈련, 하품-한숨, 음성배 치, 오남용의 제거(Kim, Chung, Oh, \& Kim, 2001)'와 같은 음성치 료기법들이 사용되었다.

본 연구에서 사용한 SOVTE 음성치료는 비교적 짧은 시간에 음 질과 성대 진동의 기능적 회복에 효과적이었으며, 이는 수술 후 보 다 적극적인 음성치료 중재가 후두미세수술 후 상처 리모델링 과정 에서 조직의 기능 회복에 도움을 준 것으로 보인다. 따라서, 수술 후 성공적인 음성 결과를 얻기 위해서는 수술 후 상처 회복과정을 주 의 깊게 모니터링하는 것이 필요하며 완전한 음성휴식 후 음성사 용은 매우 임상적으로 중요할 것이다. 또한, 상처 회복기간 동안의 음성치료는 음성외상의 재발을 예방하기 위하여 성대 조직에 지나 친 기기적 자극을 감소시킬 뿐 아니라, 적절한 기기적 자극을 줌으 로써 성대 조직의 리모델링 과정에서 염증과 반흔을 최소화하여 음성 개선의 효과를 이끌어 낼 것이다.

본 연구의 제한점으로는 통제군을 비교하지 못하고 치료 전후 
만의 결과를 비교하였다. 추후의 연구에서는 음성휴식만 취한 통 제군을 포함하여 음성휴식과 음성치료의 효과를 비교해 볼 필요 가 있겠다. 또한, 음성휴식의 종류(완전한 vs. 상대적), 환자의 음성 휴식 준수 여부, 수술 기법, 음성휴식 기간 및 음성치료 시작 시기, 음성훈련 기간, 음성훈련의 종류 등에 따라 음성 개선의 차이를 살 펴 보아 수술 후 음성재활 및 관리에 대한 증거기반 지침을 세우는 것이 필요할 것이다.

\section{REFERENCES}

Abbott, K. V., Li, N. Y., Branski, R. C., Rosen, C. A., Grillo, E., Steinhauer, K., \& Hebda, P. A. (2012). Vocal exercise may attenuate acute vocal fold inflammation. Journal of Voice, 26(6), 814.e1-814.e13.

Andrade, P. A., Wood, G., Ratcliffe, P., Epstein, R., Pijper, A., \& Svec, J. G. (2014). Electroglottographic study of seven semi-occluded exercises: LaxVox, straw, lip-trill, tongue-trill, humming, hand-over-mouth, and tongue-trill combined with hand-over-mouth. Journal of Voice, 28(5), 589-595.

Aronson, A. E. (1990). Clinical voice disorders: an interdisciplinary approach. New York, NY: Thieme.

Behrman, A., \& Sulica, L. (2003). Voice rest after microlaryngoscopy: current opinion and practice. The Laryngoscope, 113(12), 2182-2186.

Benninger, M. S., Alessi, D., Archer, S., Bastian, R., Ford, C., Koufman, J., ... \& Woo, P. (1996). Vocal fold scarring: current concepts and management. Otolaryngology—Head and Neck Surgery, 115(5), 474-482.

Béquignon, E., Bach, C., Fugain, C., Guilleré, L., Blumen, M., Chabolle, F., \& Wagner, I. (2013). Long-term results of surgical treatment of vocal fold nodules. The Laryngoscope, 123(8), 1926-1930.

Branski, R. C., Verdolini, K., Sandulache, V., Rosen, C. A., \& Hebda, P. A. (2006). Vocal fold wound healing: a review for clinicians. Journal of Voice, 20(3), 432-442.

Choi, S. H. (2017). Semi-occluded vocal tract exercise accent method, straw phonation, Lax Vox. Journal of the Korean Association for Voice of Performing Arts, 4, 11-19.

Choi, S. H. (2019). Rehabilitation and care following laryngeal surgeries. Proceedings of Choi, Hong-Shik Retirement Memorial Symposium, Seoul, Korea.

Culav, E. M., Clark, C. H., \& Merrilees, M. J. (1999). Connective tissues: matrix composition and its relevance to physical therapy. Physical Therapy, 79(3), 308-319.

Dargin, T. C., DeLaunay, A., \& Searl, J. (2016). Semioccluded vocal tract ex- ercises: changes in laryngeal and pharyngeal activity during stroboscopy. Journal of Voice, 30(3), 377.e1-377.e9.

Flavell, J. H. (1979). Metacognition and cognitive monitoring: a new area of cognitive-developmental inquiry. American Psychologist, 34(10), 906-911.

Frank, C. B. (1996). Ligament healing: current knowledge and clinical applications. Journal of the American Academy of Orthopaedic Surgeons, 4(2), 74-83.

Guzman, M., Laukkanen, A. M., Krupa, P., Horáček, J., Švec, J. G., \& Geneid, A. (2013). Vocal tract and glottal function during and after vocal exercising with resonance tube and straw. Journal of Voice, 27(4), 523.e19-523. e34.

Hansen, J. K., \& Thibeault, S. L. (2006). Current understanding and review of the literature: vocal fold scarring. Journal of Voice, 20(1), 110-120.

Harris, S. (1998). Speech therapy for dysphonia. In T. Harris and D. M. Howard (Eds.), The voice clinic handbook (pp. 139-206). London: Whurr.

Inoue, M., Woo, S. L., Gomez, M. A., Amiel, D., Ohland, K. J., \& Kitabayashi, L. R. (1990). Effects of surgical treatment and immobilization on the healing of the medial collateral ligament: a long-term multidisciplinary study. Connective Tissue Research, 25(1), 13-26.

Ishikawa, K., \& Thibeault, S. (2010). Voice rest versus exercise: a review of the literature. Journal of Voice, 24(4), 379-387.

Johns, M. M., Garrett, C. G., Hwang, J., Ossoff, R. H., \& Courey, M. S. (2004). Quality-of-life outcomes following laryngeal endoscopic surgery for nonneoplastic vocal fold lesions. Annals of Otology, Rhinology \& Laryngology, 113(8), 597-601.

Joshi, A., \& Johns, M. M. (2018). Current practices for voice rest recommendations after phonomicrosurgery. The Laryngoscope, 128(5), 1170-1175.

Ju, Y. H., Jung, K. Y., Kwon, S. Y., Woo, J. S., Cho, J. G., Park, M. W., ... \& Baek, S. K. (2013). Effect of voice therapy after phonomicrosurgery for vocal polyps: a prospective, historically controlled, clinical study. The Journal of Laryngology \& Otology, 127(11), 1134-1138.

Kaneko, M., Shiromoto, O., Fujiu-Kurachi, M., Kishimoto, Y., Tateya, I., \& Hirano, S. (2017). Optimal duration for voice rest after vocal fold surgery: randomized controlled clinical study. Journal of Voice, 31(1), 97-103.

Kang, Y. A., Chang, J. W., \& Koo, B. S. (2016). Aerodynamic features in patients with vocal polyps before $\&$ after laryngomicrosurgery. Phonetics and Speech Sciences, 8(3), 39-49.

Kim, D. I., La, S. H., \& Lee, H. E. (2016). A meta-analysis on the characteristics and effects of meta-cognitive strategic interventions in Korea: comparison between group-designed studies and single case studies. Asian 
Journal of Education, 17(3), 21-48.

Kim, H. G., Chung, P. S., Oh, Y. H., \& Kim, Y. H. (2001). A study of voice improvement according to the onset time of voice therapy after laryngomicrosurgery. Journal of the Korean Society of Laryngology, Phoniatrics and Logopedics, 12(1), 22-27.

Kim, J. H., Choi, H. G., \& Park, B. (2015). Change of voice handicap index after laryngeal microsurgery for benign vocal fold lesions. Journal of the Korean Society of Laryngology, Phoniatrics and Logopedics, 26(1), 34-39.

Kim, J. S., Lee, D. W., Choi, C. H., \& Choi, S. H. (2017). Effects of laryngeal massage and semi-occluded vocal tract exercises for patients with hyperfunctional dysphonia. Communication Sciences \& Disorders, 22(4), 806817.

Kim, M. S., Pyo, H. Y., Choi, H. S., Kim, Y. H., \& Kim, K. M. (1997). Clinical analysis of persistent and recurrent postoperative dysphonia. Journal of the Korean Society of Laryngology, Phoniatrics and Logopedics, 8(2), 225-231.

Ko, D. H. (2015). Experimental phonetics for speech-language pathologists. Seoul: Hakjisa.

Laukkanen, A. M., Lindholm, P., Vilkman, E., Haataja, K., \& Alku, P. (1996). A physiological and acoustic study on voiced bilabial fricative / $\beta$ :/ as a vocal exercise. Journal of Voice, 10(1), 67-77.

Lee, E. K., \& Son, Y. I. (2005). Muscle tension dysphonia in children: Voice characteristics and outcome of voice therapy. International Journal of Pediatric Otorhinolaryngology, 69(7), 911-917.

Lee, S. H. (2015). Non-surgical management for benign vocal fold lesions. Journal of the Korean Society of Laryngology, Phoniatrics and Logopedics, 26(2), 97-100.

Lieberman, J. (1998). Principles and techniques of manual therapy: application in the management of dysphonia. In T. Harris and D. M. Howard (Eds.), The voice clinical handbook (pp. 91-138). London: Whurr.

Menezes, M. H., Ubrig-Zancanella, M. T., Cunha, M. G. B., Cordeiro, G. F., Nemr, K., \& Tsuji, D. H. (2011). The relationship between tongue trill performance duration and vocal changes in dysphonic women. Journal of Voice, 25(4), e167-e175.

Ogawa, M., Hosokawa, K., Yoshida, M., Iwahashi, T., Hashimoto, M., \& Inohara, H. (2014). Immediate effects of humming on computed electroglottographic parameters in patients with muscle tension dysphonia. Journal of Voice, 28(6), 733-741.
Park, H. S., Park, Y. S., Choi, D. Y., Kim, S. Y., Yoo, S. J., \& Nam, S. Y. (2000).

The utility of accent method as supplementary treatment after surgery of vocal nodule and laryngeal polyp. The Journal of the Korean Society of Logopedics and Phoniatrics, 11(1), 39-45.

Petrovic-Lazic, M., Jovanovic, N., Kulic, M., Babac, S., \& Jurisic, V. (2015). Acoustic and perceptual characteristics of the voice in patients with vocal polyps after surgery and voice therapy. Journal of Voice, 29(2), 241-246.

Roy, N., Bless, D. M., Heisey, D., \& Ford, C. N. (1997). Manual circumlaryngeal therapy for functional dysphonia: an evaluation of short-and longterm treatment outcomes. Journal of Voice, 11(3), 321-331.

Senemoglu, N. (2005). Development, learning and teaching: from theory to practice. Ankara: Gazi Bookstore.

Shin, Y. S., Chang, J. W., Yang, S. M., Wu, H. W., Cho, M. H., \& Kim, C. H. (2013). Persistent dysphonia after laryngomicrosurgery for benign vocal fold disease. Clinical and Experimental Otorhinolaryngology, 6(3), 166-170.

Titze, I. R. (2006). Voice training and therapy with a semi-occluded vocal tract: rationale and scientific underpinnings. Journal of Speech, Language, and Hearing Research, 49(2), 448-459.

Toran, S., \& Lal, B. K. (2010). Objective voice analysis for vocal polyps following microlaryngeal phonosurgery. Kathmandu University Medical Journal, 8(2), 185-189.

Van Lierde, K. M., De Ley, S., Clement, G., De Bodt, M., \& Van Cauwenberge, P. (2004). Outcome of laryngeal manual therapy in four Dutch adults with persistent moderate-to-severe vocal hyperfunction: a pilot study. Journal of Voice, 18(4), 467-474.

Vinney, L. A., \& Turkstra, L. S. (2013). The role of self-regulation in voice therapy. Journal of Voice, 27(3), 390.e1-390.e11.

Woo, P., Casper, J., Colton, R., \& Brewer, D. (1994). Diagnosis and treatment of persistent dysphonia after laryngeal surgery: a retrospective analysis of 62 patients. The Laryngoscope, 104(9), 1084-1091.

Yun, Y. S., Kim, H., Son, Y. I., \& Choi, H. S. (2008). Validation of the Korean Voice Handicap Index (K-VHI) and the clinical usefulness of Korean VHI10. Korean Journal of Communication \& Disorders, 13(2), 216-241.

Zeitels, S. M. (2000). New procedures for paralytic dysphonia: adduction arytenopexy, Goretex* medialization laryngoplasty, and cricothyroid subluxation. Otolaryngologic Clinics of North America, 33(4), 841-853. 


\section{국문초록}

\section{후두미세수술 이후 지속되는 발성장애의 음성치료 효과}

\section{김지성 ${ }^{1,2} \cdot$ 최성희 ${ }^{3} \cdot$ 최철희 ${ }^{3} \cdot$ 이동욱 $^{4}$}

${ }^{1}$ 대구가톨릭대학교 대학원, ${ }^{2}$ 충북대학교병원 이비인후과, ${ }^{3}$ 대구가톨릭대학교 언어청각치료학과, ${ }^{4}$ 충북대학교 의과대학 이비인후-두경부외과학교실

배경 및 목적: 후두미세수술은 성대의 접촉을 방해하는 병변의 제거를 통해 성대 접촉면을 부드럽게 만들어 음질을 향상시키고 음성 기능을 회복시키는 데 효과적인 방법이다. 하지만 후두미세수술 이후에도 음성문제가 지속되는 경우가 있다. 본 연구의 목적은 후두미 세수술 이후에도 지속되는 음성문제의 개선을 위해 실시한 음성치료의 효과를 알아보고자 한다. 방법: 성대 결절과 성대 폴립으로 인 해 후두미세수술을 받았으나 수술 이후에도 음성문제가 지속되는 여성 14명을 대상으로 하였다. 대상자들은 SOVTE (반폐쇄성도운 동)와 후두마사지로 구성된 음성치료를 받았다. 음성치료의 효과를 확인하기 위해 치료 전후 청지각적 평가, 음향학적 분석 및 KVHI-10을 실시하고 이를 비교하였다. 결과: 음성치료 후 음향학적 매개변수인 STD, \% itter, PPQ, vF0, \%Shimmer, APQ, vAm, NHR, $\mathrm{DSH}$ 가 유의하게 감소하였고, 청지각적 평가에서는 Grade, Breathy와 Strained 척도가 유의하게 감소하였으며, K-VHI-10 점수 역시 유 의하게 감소되었다. 논의 및 결론: 반폐쇄성도운동과 후두마사지는 수술 전부터 지속되어 왔던 잘못된 발성 패턴을 수정하고 수술 후 지속되는 음성문제를 개선시키는 데 효과적이었다. 따라서, 음성치료는 수술 후 음성휴식과 음성위생만으로는 해결할 수 없는 성대의 기능적 회복에 도움을 줄수 있을 것이다.

핵심어: 후두미세수술, 발성장애, 음성치료, 상처회복

\section{참고문헌}

강영애, 장재원, 구본석(2016). 성대용종 환자의 후두미세수술 전후 공기역학 변수 변화. 말소리와음성과학, 8(3), 39-49.

고도흥(2015). (언어치료사를 위한) 음성언어의 측정, 분석 및 평가. 서울: 학지사.

김동일, 라수현, 이혜은(2016). 메타인지전략의 효과에 관한 메타분석: 집단설계연구와 단일사례연구의 비교. 아시아교육연구, 17(3), 21-48.

김명상, 표화영, 최홍식, 김영호, 김광문(1997). 후두미세수술후 지속적인 음성장애환자에 대한 임상적 고찰. 후두음성언어의학회지, 8(2), 225-231.

김지성, 이동욱, 최철희, 최성희(2017). 후두마사지와 반폐쇄성도훈련이 과기능적 음성장애 환자의 음성개선에 미치는 효과. Communication Sci-

ences \& Disorders, 22(4), 806-817.

김지희, 최효근, 박범정(2015). 양성 후두 질환 환자의 후두미세 수술 전후음성 장애 지수의 변화. 후두음성언어의학회지, 26(1),34-39.

김한균, 정필상, 오양희, 김영훈(2001). 레이저를 이용하여 후두미세수술을 시행한 환자에서 음성치료를 시작한 시기에 따른 음성 호전 결과에 관한

연구. 후두음성언어의학회지, 12(1), 22-27.

박혜성, 박영실, 최두영, 김상윤, 유승주, 남순열(2000). 성대 결절 및 후두 폴립의 수술 후 보충 치료로서 Accent Method의 유용성. 대한음성언어의

학회지, 11(1), 39-45.

윤영선, 김향희, 손영익, 최홍식(2008). 한국어판 음성장애지수(Voice Handicap Index, VHI)의 타당도 및 VHI-10의 임상적 유용성. 언어청각장애연

구, 13(2), 216-241.

이상혁(2015). 양성 성대 병변의 비수술적 치료. 후두음성언어의학회지, 26(2), 97-100.

최성희(2017). 공연예술가를 위한 반폐쇄성도훈련: 악센트기법, 빨대발성, Lax Vox. 한국공연예술발성연구회지, 4, 11-19.

최성희(2019). 후두미세수술 이후 음성관리와 재활. 최홍식교수 정년퇴임기념 심포지엄 논문집.

\section{ORCID}

김지성(https://orcid.org/0000-0003-2363-5060); 최성희(https://orcid.org/0000-0003-2365-6187);

최철희(https://orcid.org/0000-0003-1844-3072); 이동욱(https://orcid.org/0000-0002-3333-6083) 